\title{
CULTURAL FOUNDATIONS OF RIGHT-WING POLITICS IN THE UNITED STATES: THE CASE OF THE TEA PARTY MOVEMENT
}

\author{
Kenneth D. Wald, University of Florida \\ Andrea Peña Vasquez, University of Notre Dame \\ E-post kenwald@ufl.edu
}

\begin{abstract}
Although the United States has long experienced a two-party electoral system, that framework has frequently been roiled by intra-party insurgencies fueled by social movements (Markoff 2015, Miroff 2007), Such disturbances often raise new issues and put apparently settled questions back on the political agenda. Shortly after the 2008 presidential election in the United States, the Tea Party emerged as a major challenge to the norms of the Republican party (Burghart and Zeskind 2010). The upsurge of activism against party elites, manifested in divisive primaries that ended the careers of several prominent Republican elected officials, has abated somewhat but moderate Republican officials still cite fear of a contested primary against a Tea Party candidate to justify their votes on various proposals (Edsall 2017).
\end{abstract}


As such movements typically do, we argue in this paper, the Tea Party represented an opportunity to reorder the Republican agenda by putting a set of cultural issues at the center of party discourse. These issues and concerns were not altogether new, having been a part of the political agenda for some time, but they were not priority issues on the Republican legislative agenda or were issues that the party elite had been unable to act upon due to internal divisions. The success of the Tea Party showed, as political consultants would say, that the concerns of the movement had legs.

This became apparent in 2016 when the Donald Trump presidential campaign appropriated many of the core themes and positions associated with the Tea Party. Inglehart and Norris (2017) have argued that Trump's surprising victory, like the Brexit vote in Britain and the growth of the National Front in France, represents the phenomenon of "populist authoritarianism." They interpret the electoral growth of this syndrome to a "backlash against cultural change." More specifically, they contend that such parties have gained support among voters facing both declining "existential security" due to highly class-skewed economic growth and "a large influx of immigrants and refugees" who can be held responsible for unsettling social changes. Trump's campaign capitalized on these anxieties by focusing both on the economic insecurity of working and middle-class Americans and on the threats posed by the newcomers.

We show in this paper how the Tea Party appealed disproportionately to voters in cultural terms. providing a model that the Republican presidential nominee would use successfully less than a decade later. The Tea Party tapped deep-seated cultural cleavages in the American polity that Trump later emphasized: economic grievances, racial and ethnic tension, anti-government sentiment, religious nationalism, and moral traditionalism. The relationship is inferential, of course, but sufficiently compelling to present the Tea Party as a vehicle for the development of an electoral strategy that later paid electoral dividends.

We begin by arguing in favor of a cultural politics framework as a means of integrating otherwise disparate explanations of Tea Party support in the mass public. The paper then describes the data-set used for empirical analysis and the basic design of the analysis. Following an exposition of the statistical results, we discuss how the Tea Party's success in bridging divides on the political right foreshadowed subsequent Republican campaign discourse.

\section{A theory of cultural politics}

We draw on the variant of cultural theory developed extensively by Leege and his colleagues (Leege, Lieske \& Wald 1991; Leege 1992; Leege et al 2002; Leege \& Wald 2007; Wald \& Leege 2009, 2010). This approach differs from Hunter's $(1991,1994)$ well-known "culture wars" model by broadening it beyond a clash between religious traditionalists and religious progressives and extends the approach of Inglehart and Norris (2017) by emphasizing the role of the political system in translating grievances into concrete political action. 
As Mockabee $(2007,227)$ has pointed out, one does not have to be religious to favor what are called traditional values. Consistent with that view, Leege et al argue that religion is only one domain of cultural conflict, not the whole of it. Rather, they argue that cultural conflict is "not just the subject matter of a political debate - particular issues involving abortion, women's rights, school prayer - but rather any political controversy that turns on conflicts about social values, norms, and symbolic community boundaries" (Leege et al. 2002, p. 27). The authors show how the politics of cultural differences encompasses not only differing religious beliefs but also broad conflicts over foreign policy, social welfare, and debates about race, gender, and immigration. In the contemporary era, these issues can be framed in ways that raise questions about, for example, the worthiness of recipients of governmental assistance, the patriotism of those who argue against demonizing Muslims, and the morality of those who wish to change the public-school curriculum by emphasizing social and cultural diversity.

Leege et al put what Wuthnow (1987) called "moral orders" at the center of cultural conflict. Following the "cultural turn" in the social sciences, they treat culture as "a distinct sphere of human activity in which society transmits meaning through specialized institutions that enable individuals to locate themselves in the social order" (Wald \& Leege 2010, 130). This approach emphasizes how culture provides individuals with bearings to address major existential questions: Who am I? By extension, who is the "the other," the one not like me? What shall I do?

As Ann Swidler (1986) famously put it, cultures provide "toolkits" that help individuals work out courses of action in unsettled times. People do not typically come up with answers to such questions via abstract reasoning; rather, individuals develop their perspectives on these existential concerns through their experience of social relations (Wildavsky 1987). This produces not a unitary culture but a plethora of subcultures with distinctive views about the nature and purposes of social existence.

These efforts become fodder for politics when ambitious politicians exploit subgroup cultural differences to mobilize constituencies around a common political objective. In the politics of cultural differences, political actors draw on tools such as relative deprivation, fear and anxiety, often deploying "efficient symbols" that weave together the sources of social unrest (e.g., Willie Horton). They then attempt to attach those symbols to the opposing political party, hoping to reduce its electoral appeal to its own base.

To take just one example, a political entrepreneur in Florida attending a Right to Life conference heard a presentation about "intact dilation and extraction," a rarely-used medical procedure to terminate late-term pregnancies threatening the life of the mother. Alert to cultural cleavages about questions of life, he recognized the potential of this procedure, properly framed, to alter the abortion debate by likening the practice as rather closer to infanticide than the principled exercise of choice by a pregnant woman. With a politician's instinct for effective labels, he picked up on critics' description of the medical procedure as "partial-birth abortion" and introduced legislation to ban the practice (Rovner 2006). 
This theory of cultural differences encompasses most of the unitary frames that have been deployed by scholars to explain mass support for the Tea Party-religion, nationalism, political alienation, race, and partisanship. ${ }^{1}$ Tying these themes together, the influential political psychologist Jonathan Haidt described a defensive syndrome exhibited by Americans who perceive that "the moral order is falling apart, the country is losing its coherence and cohesiveness, diversity is rising, and our leadership seems to be suspect or not up to the needs of the hour." When worried Americans are confronted with these challenges, he argued further, "It's as though a button is pushed on their forehead that says, 'in case of moral threat, lock down the borders, kick out those who are different, and punish those who are morally deviant"" (quoted in Edsall 2016).

In practice, Tea Party elites appeared to follow the script of cultural mobilization, using "fearbased frames and narratives" in which opponents were "demonized and scapegoated" as "dangers to America" (Berlet 2012, 48). Antagonism toward illegal immigrants, which might well arise due to concerns over competition for jobs and resources, was instead reframed as a frontal assault on American culture by both academics (Huntington 2004) and movement activists who associated themselves with a hallowed symbol, the Minutemen of the Revolutionary era (Chavez 2008). By portraying President Obama as a Muslim post-colonialist socialist who hates whites (Postel 2012, 41), Tea Party activists made him a symbol of all they rejected and then used that construct to delegitimize virtually all Obama Administration initiatives. The Tea Party movement also appealed to the fears among white Anglo Christians that their faith and values were being displaced from the public square by growing religious diversity in the United States (Jones 2016). In making sense of the Tea Party, the politics of cultural differences provides a theoretical canopy that covers the partisan, religious, political and racial themes widely employed by other scholars.

\section{Data and design}

We analyze data on Tea Party support from the 2012 "Race, Class and Culture Survey" developed by the Public Religion Research Institute (PRRI). The telephone survey of a nationally-representative sample of 2501 American adults was conducted just a few months before the 2012 presidential election when the movement's mass support appeared at its peak.

The dependent variable was constructed by items that asked respondents (1) if they believed the Tea Party shared their values and (2) whether respondents considered themselves part of the Tea Party movement. Using these items captures both value congruence and identification with the movement. The base of social movements typically shrinks as the constituency is narrowed from those agree who with some movement issue positions to those with a positive affect for movement organizations (Sigelman \& Presser 1988). Some of the policies associated with the Tea Party were embraced by majorities or near majorities of the sample - dissatisfaction with the state of the nation and President Obama, belief that public assistance programs sap the will to work, and support for cutbacks in government services and decreases in federal taxes. Yet only about a third of that potential constituency believed the Tea Party shared their values, and barely a tenth considered themselves part of the movement. 
Following Parker \& Barreto $(2013,74)$, we created a three-value indicator of Tea Party support based on these items. Respondents who said the movement did not share their values nor identified with it were assigned the lowest value while those who said yes to both questions were coded at the maximum. We allocated respondents offering any other combination of responses to these two questions to an intermediate category. This scheme approximates Parker and Barreto's "true believer," "middle of the road," and "true skeptic" categories. Figure 1 shows the distribution of respondents on the dependent variable.

\section{Figure 1. Tea Party Orientation (precent of repsondents).}

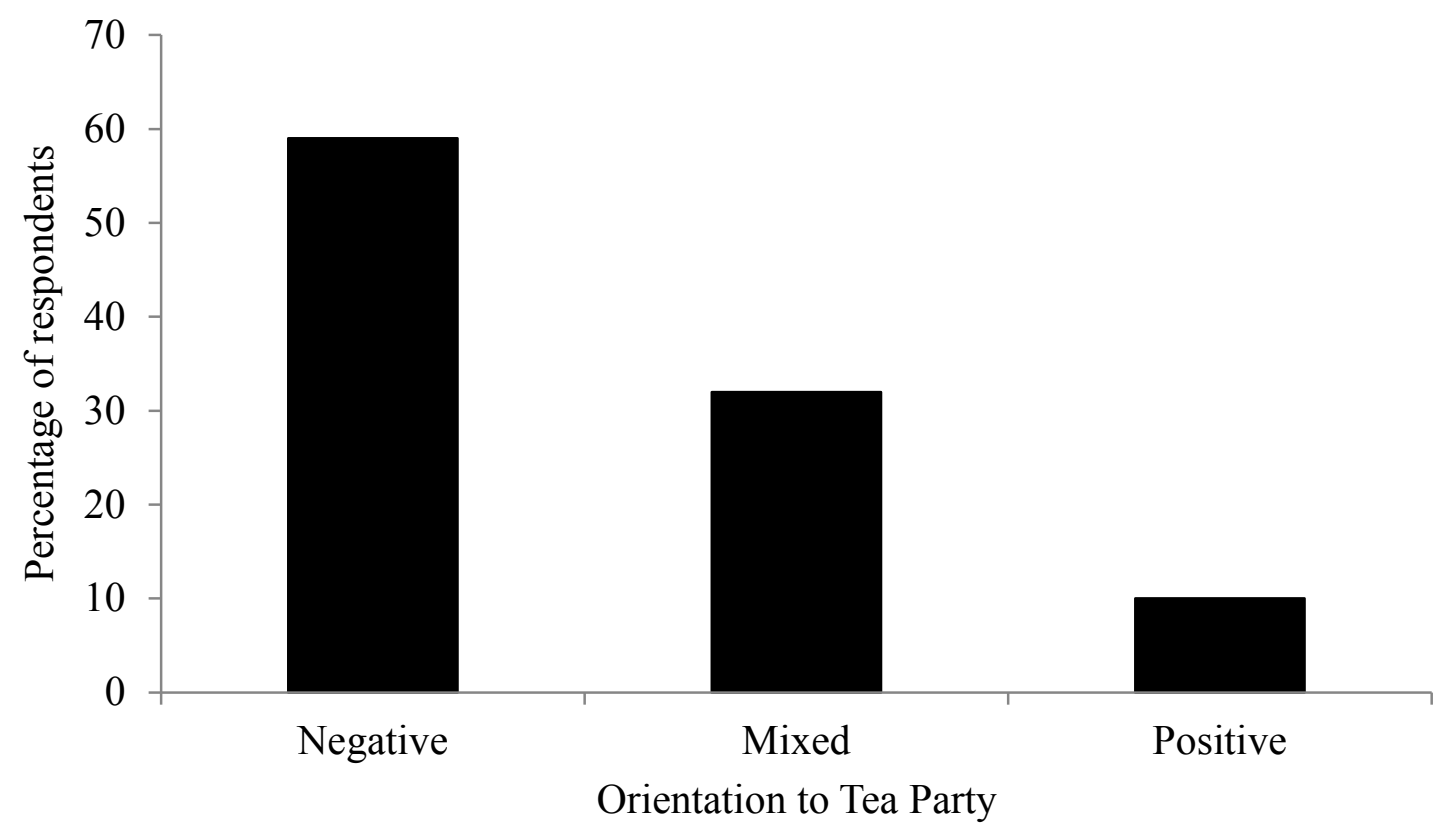

The likely predictors of Tea Party support were entered in seven tiers. Borrowing from the framework of the classic American Voter (Campbell, Converse, Miller \& Stokes, 1960), we started with factors most distant from the immediate object of our inquiry - the Tea Party in 2012 - and moved gradually closer to potential influences much more proximate to the conditions at the time the survey was conducted. As we move from broad to narrower forces, we can determine which variables operate directly on the dependent variable and identify predictors that are potentially mediated by other factors in the model.

The baseline model included six exogenous demographic variables: sex, race, age, marital status, education and self-identified social class. ${ }^{2}$ For variables in this set lacking a natural ordering like age or years of education, predictors were coded in the direction suggested by previous research so higher values on sex, race and marital status were assigned, respectively, to men, whites, and married people.

The second, third and fourth tiers added variables related to the religious interpretation of the Tea Party. The first tier entered after the base model incorporated variables denoting religious identity using dummy variables for Roman Catholics, Jews, Mormons, the religiously 
unaffiliated, and members of non-Christian faiths. The Protestant plurality was subdivided between white Evangelicals and Mainliners depending on whether they considered themselves to have been born again or not. African American Protestants were assigned their own unique category. Those who reject religion by describing themselves as atheists or agnostics were the comparison category. (See Steensland et al. 2000 for discussion of this categorization.) In model 3 , we added religious belief/behavior items - church attendance, two questions about the Bible, and one question about the salience of religion to respondents. The fourth tier included two political issues largely debated in overt religious terms in 2012: same-sex marriage and abortion, both coded in a right-wing direction.

Model 5 brings in social values (other than overt religious measures) that have been the currency of cultural politics: a composite measure of respect for authority based on child-rearing preferences (modeled on Mockabee 2007); four questions about immigration coded in an antiimmigrant direction; two items tapping religious nationalism (God has allotted the US a special role in human history and the US is a Christian country); and racial traditionalism, created by combining items about discrimination against whites and government preferences for minorities. These are considered "cultural" issues - some because they reflect concerns about "the other," groups and individuals who might be unworthy of governmental favoritism (immigrants, racial minorities) and some which privilege a Christian identity for the US (Jacobs $\&$ Theiss-Morse 2013). They epitomize the "us vs. them" dynamic thought to actuate Tea Party mobilization.

The last two models incorporate factors assumed to be more immediate in their influence on political judgments. Model 6 adds two measures of political alienation often articulated by rankand-file participants in Tea Party gatherings - dissatisfaction with the state of the country and disapproval of President Obama's job performance. Model 7 incorporates partisan and ideological dispositions routinely invoked in accounts of the Tea Party: Republican partisanship, conservative self-identification, and media exposure to right-wing perspectives via Fox News and talk radio. Both Fox and talk radio were key conduits publicizing the Tea Party and recruiting members to it. Entering these models in the final step constituted a stiff test of the direct explanatory power of potential determinants identified in prior research about the Tea Party.

\section{Data analysis}

We calculated a series of OLS regression equations to predict support for the Tea Party among individuals. ${ }^{3}$ To ensure that changes in coefficients across models are not due to attrition from missing values as we add new variables, we used multiple imputation to replace the missing values for most variables and report the pooled regression coefficients from the five imputed datasets.

The baseline demographic model in Table 1 (Model 1) largely follows the findings of previous studies. Tea Party support was higher among men, married people and whites and dropped with 
increases in education. Neither age nor self-described social class had a significant linear effect on disposition toward the Tea Party.

The second model in Table 1 introduces the measures of religious belonging. The coefficients in Model 2 represent the differences between each group and the omitted category, the antireligious respondents who explicitly defined themselves as atheists or agnostics. Catholics, Mormons, white Evangelical Protestants and Mainline Protestant were all significantly more likely to offer a positive view of the Tea Party than the anti-religious while Jews, other nonChristians, African American Protestants and those without a religious identity were indistinguishable from the explicitly anti-religious respondents. Adding these measures of religious group membership did not diminish the influence of gender, marital status, race nor education noted in Model 1.

Tabell 1. Models of Tea Party Identification: Demography and Religious Identification.

\begin{tabular}{|c|c|c|c|c|c|c|c|c|}
\hline & \multicolumn{4}{|c|}{ Model 1: Demography } & \multicolumn{4}{|c|}{ Model 2: Religious Identification } \\
\hline & $\begin{array}{r}\text { Coeff- } \\
\text { icient }\end{array}$ & $\mathrm{t}$ & S.E & $\mathrm{P}>|\mathrm{z}|$ & $\begin{array}{r}\text { Coeff- } \\
\text { icient }\end{array}$ & $\mathrm{t}$ & S.E & $\mathrm{P}>|\mathrm{z}|$ \\
\hline Male & $.131 * *$ & 4.511 & .029 & .000 & $.132 * *$ & 4.625 & .028 & .000 \\
\hline Class & -.035 & -.1682 & .021 & .093 & -.027 & -1.324 & .020 & .186 \\
\hline Married & $.117^{* *}$ & 3.896 & .030 & .000 & .061 & 2.068 & .030 & .039 \\
\hline Age & .001 & 1.388 & .001 & .167 & .001 & 1.038 & .001 & .301 \\
\hline Education & $-.032 * *$ & -3.719 & .008 & .000 & $-.024 *$ & -2.823 & .008 & .005 \\
\hline White & $.204^{* *}$ & 5.498 & .037 & .000 & & & & \\
\hline Roman Catholic & & & & & $.307 * *$ & 5.055 & .061 & .000 \\
\hline Latter-Day Saints & & & & & .219 & 1.986 & .110 & .048 \\
\hline Jewish & & & & & .085 & .770 & .110 & .441 \\
\hline Misc. Non-Christians & & & & & .190 & 1.760 & .108 & .078 \\
\hline No Religious Identity & & & & & .118 & 1.925 & .061 & .054 \\
\hline Evangelical Protestant & & & & & $.450^{* *}$ & 8.055 & .056 & .000 \\
\hline Mainline Protestant & & & & & $.286^{* *}$ & 4.528 & .063 & .000 \\
\hline Black Protestant & & & & & -.041 & -.654 & .063 & .513 \\
\hline $\mathrm{R}^{2}$ & .0456 & & & & .085 & & & \\
\hline Number of cases & 2447 & & & & 2447 & & & \\
\hline
\end{tabular}

Note: $* \mathrm{p} \leq .01 ; * * \mathrm{p} \leq .001$

Model 3 (Table 2) incorporates religious belief and behavior. Traditional attitudes toward the Bible and high levels of religious salience predicted support for the Tea Party but church attendance had no discernible impact. Except for Mormons, all the religious groups that were more favorable to the Tea Party in Model 2 retained that status in Model 3. However, African American Protestants emerged in Model 3 as significantly less supportive of the movement than even atheists and agnostics. Of the demographic factors significant in Model 1, only gender 
continued to exert a significant influence with men remaining more supportive of the movement than women.

The next model in Table 2 includes contentious issues debated with explicit reference to religious values - same-sex marriage and abortion. Opposition to these practices significantly enhanced value congruence and identification with the Tea Party. While religious salience continued to exert a positive and significant impact on Tea Party orientation in Model 4, traditionalist beliefs in the Bible as divinely inspired and literally true dropped out, apparently mediated by attitudes to abortion and same-sex marriage. Despite these new controls, respondents from the Catholic, Evangelical Protestant, and Mainline Protestant traditions continued to be more supportive of the Tea Party (compared to the anti-religious) and black Protestants remained significantly more negative. Males also continued to show more positive disposition to the Tea Party in model 4.

Tabell 2. Models of Tea Party Identification: Religious Belief/Behavior and Overt Religious Issues.

\begin{tabular}{lrrrrrrrr}
\hline & \multicolumn{7}{c}{ Model 3: Religious Belief/Behavior } & \multicolumn{3}{c}{ Model 4: Overt Religious Issues } \\
\hline & $\begin{array}{r}\text { Coeff- } \\
\text { icient }\end{array}$ & $\mathrm{t}$ & $\mathrm{S} . \mathrm{E}$ & $\mathrm{P}>|\mathrm{z}|$ & $\begin{array}{r}\text { Coeff- } \\
\text { icient }\end{array}$ & $\mathrm{t}$ & $\mathrm{S} . \mathrm{E}$ & $\mathrm{P}>|\mathrm{z}|$ \\
\hline Male & $.155^{* *}$ & 5.397 & .029 & .000 & $.107^{* *}$ & 3.658 & .029 & .000 \\
Class & -.025 & -1.223 & .020 & .221 & -.027 & -1.354 & .020 & .176 \\
Married & .047 & 1.576 & .030 & .115 & .039 & 1.329 & .029 & 1.84 \\
Age & .001 & .697 & .001 & .487 & .000 & -.233 & .001 & .816 \\
Education & -.013 & -1.524 & .009 & .128 & -.004 & -.459 & .009 & 646 \\
Roman Catholic & .162 & 2.446 & .066 & .015 & .149 & 2.270 & 065 & .024 \\
Latter-Day Saints & .008 & .071 & .115 & .944 & -.050 & -.447 & .113 & .655 \\
Jewish & -.003 & -.031 & .110 & .975 & .023 & .212 & .108 & .832 \\
Misc. Non-Christians & .068 & .624 & .109 & .533 & .081 & .756 & .107 & .450 \\
No Religious Identity & .065 & 1.055 & .062 & .292 & .047 & .772 & .061 & .440 \\
Evangelical Protestant & $.224^{* *}$ & 3.416 & .066 & .001 & .165 & 2.536 & .065 & .011 \\
Mainline Protestant & .155 & 2.308 & .067 & .022 & .146 & 2.240 & .065 & .026 \\
Black Protestant & $-.249^{* *}$ & -3.529 & .071 & .000 & $.231 * *$ & -3.335 & .069 & .001 \\
Biblical Literalism & $.087^{* *}$ & 3.993 & .022 & .000 & .027 & 1.207 & .022 & .228 \\
Attendance & -.006 & -.498 & .012 & .619 & -.018 & -1.582 & .012 & .115 \\
Salience & $.059^{* *}$ & 3.370 & .017 & .001 & .042 & 2.411 & .017 & .017 \\
Pro-life & & & & & $.080^{* *}$ & 4.543 & .018 & .000 \\
Traditional Marriage & & & & & $.091 * *$ & 6.096 & .015 & .000 \\
\hline R & & & & & .142 & & & \\
Number of cases & 2447 & & & & 2447 & & & \\
\hline
\end{tabular}

Notes: $* \mathrm{p} \leq .01 ; * * \mathrm{p} \leq .001$

Table 3 presents the next two steps in extending the baseline model. Model 5 incorporates a series of variables centrally associated with the politics of cultural differences - attitudes about 
race, gender, sexuality, child-rearing practices and religious exceptionalism in American identity. If support for the Tea Party draws on anger about perceived violations of the moral order embedded in subcultures, these variables should promote attachment to the Tea Party. We found that neither authority-mindedness (based on preferred traits for children) nor the four immigration items contributed significantly to the dependent variable. On the other hand, the composite measure of racial traditionalism and the two items tapping religious nationalism (belief that the US has a special relationship with God and that the US is a Christian country) emerged as positive, powerful, and direct influences on Tea Party support.

Even with these cultural variables added to the model, men, respondents with high levels of religious salience, and black Protestants were still distinctive, the first two groups more likely to embrace the Tea Party, the latter exhibiting antipathy. Perhaps because evangelical Protestants have such strong beliefs about the divine character and Christian religious identity of the United States, the dummy variable for white evangelicals did not contribute significantly in Model 5.

By this point in the analysis, it seems, most of the religious identity and belief measures have ceased to exert a direct impact on Tea Party affect. Their influence appears to be channeled through more proximate measures involving views on issues often debated through a religious idiom (abortion and same-sex marriage), religious conceptions of nationalism, racial traditionalism and a personal sense of religious salience.

The next to last model (Table 3) tests for the principal political tropes heard at Tea Party gatherings, disappointment in the direction of the United States and disapproval of President Obama. In Model 6, we found that generalized dissatisfaction with the state of the country did not influence Tea Party affect while disapproval of President Obama did so, most decidedly. These new factors did not much alter our conclusions from earlier models. Racial traditionalism, religious nationalism, and a pro-life orientation continued to promote adherence to the movement. As in earlier models, men were more supportive than women and African American Protestants less positive than the anti-religious. 
Tabell 3. Models of Tea Party Identification: Religious Belief/Behavior and Overt Religious Issues.

\begin{tabular}{|c|c|c|c|c|c|c|c|c|}
\hline & \multicolumn{4}{|c|}{ Model 5: Cultural Factors } & \multicolumn{4}{|c|}{ Model 6: Alienation } \\
\hline & $\begin{array}{r}\text { Coeff- } \\
\text { icient } \\
\end{array}$ & $\mathrm{t}$ & S.E & $\mathrm{P}>|\mathrm{z}|$ & $\begin{array}{r}\text { Coeff- } \\
\text { icient } \\
\end{array}$ & $\mathrm{t}$ & S.E & $\mathrm{P}>|\mathrm{z}|$ \\
\hline Male & $.135 * *$ & 4.509 & .030 & .000 & $.118^{* *}$ & 3.942 & .030 & .000 \\
\hline Class & -.021 & -1.089 & .019 & .276 & -.018 & -.939 & .019 & .348 \\
\hline Married & .035 & 1.223 & .029 & .222 & .013 & .470 & .028 & .638 \\
\hline Age & -.001 & -1.032 & .001 & .304 & -.001 & -1.301 & .001 & .196 \\
\hline Education & .008 & .958 & .008 & .338 & .001 & .116 & .008 & .907 \\
\hline Roman Catholic & .050 & .778 & .065 & .438 & .044 & .693 & .063 & .490 \\
\hline Latter-Day Saints & -.194 & -1.717 & .113 & .088 & -.215 & -1.935 & .111 & .054 \\
\hline Jewish & .034 & .320 & .105 & .749 & .028 & .278 & .102 & .781 \\
\hline Misc. Non-Christians & .070 & .680 & .103 & .496 & .154 & 1.512 & .102 & .131 \\
\hline No Religious Identity & .031 & .529 & .060 & .597 & .038 & .652 & .058 & .515 \\
\hline Evangelical Protestant & .056 & .871 & .064 & .384 & .017 & .270 & .063 & .787 \\
\hline Mainline Protestant & .048 & .743 & .064 & .459 & .026 & .412 & .063 & .681 \\
\hline Black Protestant & $-.231 * *$ & -3.328 & .069 & .001 & -.139 & -2.037 & .068 & .042 \\
\hline Biblical Literalism & -.014 & -.638 & .022 & .523 & -.007 & -.315 & .022 & .753 \\
\hline Attendance & -.012 & -1.095 & .011 & .275 & -.007 & -.579 & .011 & .563 \\
\hline Salience & .034 & 2.002 & .017 & .047 & .027 & 1.663 & .017 & .098 \\
\hline Pro-life & $.067 * *$ & 3.983 & .017 & .000 & $.052 *$ & 3.119 & .017 & .003 \\
\hline Traditional Marriage & $.053 * *$ & 3.504 & .015 & .000 & .024 & 1.582 & .015 & .114 \\
\hline Authority Scale & -.006 & -1.034 & .006 & .302 & -.006 & -.967 & .006 & .334 \\
\hline Immigrant job loss & .012 & .945 & .013 & .345 & .013 & 1.010 & .013 & .313 \\
\hline Immigrant problem & .007 & .357 & .020 & .722 & .003 & .170 & .020 & .866 \\
\hline Immigrant citizenship & .029 & 1.930 & .015 & .056 & .010 & .713 & .014 & .477 \\
\hline Immigration salience & .059 & .742 & .080 & .468 & .086 & 1.093 & .078 & .289 \\
\hline Civil Religion & $.077 * *$ & 5.361 & .014 & .000 & $.075^{* *}$ & 5.283 & .014 & .000 \\
\hline Christian Nation & $.116^{* *}$ & 5.843 & .020 & .000 & $.102 * *$ & 5.283 & .019 & .000 \\
\hline Traditional Race & $.066^{* *}$ & 7.222 & .009 & .000 & .044 & 4.670 & .016 & .083 \\
\hline Dissatisfaction & & & & & $.028 * *$ & 1.738 & .017 & .000 \\
\hline Anti-Barack Obama & & & & & $.152 * *$ & 8.871 & .009 & .000 \\
\hline $\mathrm{R}^{2}$ & .2136 & & & & .2566 & & & \\
\hline Number of cases & 2447 & & & & 2447 & & & \\
\hline
\end{tabular}

Notes: ${ }^{*} \mathrm{p} \leq .01 ; * * \mathrm{p} \leq .001$ 
In Model 7, the final equation, we entered three variables that tapped political factors strongly associated with support for the Tea Party in all prior research - conservative self-identification, Republican partisanship, and exposure to right-wing news sources. The final model (Table 4) shows the results. Unsurprisingly all three variables in this tier measurably increased support for the Tea Party. They did so without undermining the direct impact of several variables that exerted a strong impact on Tea Party affect in the earlier models. Specifically, disapproval of President Obama, religious nationalism (via two variables), racial traditionalism, and hostility to abortion continued to build support for the movement in the final model. As in all prior models, men were significantly more positively disposed than women to the Tea Party.

However, virtually all the core religious measures based on belonging (identification with religious families), and believing (views about the Bible) appear to have been mediated through political forces and attitudes associated with cultural values and national identity. The reported salience of one's religious beliefs, once described as the master variable accounting for religious mobilization on social issues (Guth and Green 1993), no longer remained an important contributor to Tea Party identification. Of the religious identification variables, only affiliation with the Latter-Day Saints remained significant (reducing Tea Party attraction). Even being an African American Protestant was no longer a significant direct influence on orientations to the Tea Party.

As a check on these findings, we also conducted a parallel analysis using an MLE model (not shown). The final model showed essentially the same profile of Tea Party value congruence and identification as the OLS analysis. Men, self-identified conservatives, persons who relied mostly on conservative media outlets, those who disapproved of President Obama, and Republican identifiers were more likely than others to share the values and identify with the Tea Party. Similarly, both kinds of statistical models yielded strong positive coefficients for religious nationalism, racial traditionalism, and pro-life orientation on abortion. ${ }^{4}$ 
Tabell 4. Models of Tea Party Identification: Partisan Factors.

\begin{tabular}{|c|c|c|c|c|}
\hline & \multicolumn{4}{|c|}{ Model 7: Partisan Factors } \\
\hline & $\begin{array}{r}\text { Coeff- } \\
\text { icient }\end{array}$ & $\mathrm{t}$ & S.E & $P>|z|$ \\
\hline Male & $.083 *$ & 3.004 & .028 & .004 \\
\hline Class & -.033 & -1.704 & .018 & .089 \\
\hline Married & -.011 & -.413 & .027 & 679 \\
\hline Age & .000 & -.521 & .001 & .603 \\
\hline Education & -.006 & -.473 & .008 & .636 \\
\hline Roman Catholic & .032 & .521 & .060 & .603 \\
\hline Latter-Day Saints & -.280 & -2.535 & .107 & .012 \\
\hline Jewish & .041 & .475 & .098 & .635 \\
\hline Misc. Non-Christians & .181 & 1.896 & .099 & .058 \\
\hline No Religious Identity & .018 & .400 & .056 & .689 \\
\hline Evangelical Protestant & -.019 & -.251 & .060 & .802 \\
\hline Mainline Protestant & .003 & .109 & .061 & .913 \\
\hline Black Protestant & -.108 & -1.566 & .066 & .117 \\
\hline Biblical Literalism & -.009 & -.457 & .021 & .648 \\
\hline Attendance & -.015 & -1.334 & .011 & .184 \\
\hline Salience & .027 & 1.629 & .016 & .104 \\
\hline Pro-life & .036 & 2.191 & .016 & .033 \\
\hline Traditional Marriage & .002 & .068 & .015 & .945 \\
\hline Authority Scale & -.008 & -1.425 & .006 & .155 \\
\hline Immigrant job loss & .009 & .682 & .013 & .496 \\
\hline Immigrant problem & .005 & .247 & .020 & .806 \\
\hline Immigrant citizenship & .006 & .440 & .014 & .661 \\
\hline Immigration salience & .102 & 1.372 & .075 & .186 \\
\hline Civil Religion & $.061 * *$ & 4.405 & .014 & .000 \\
\hline Christian Nation & $.074 * *$ & 3.833 & .019 & .000 \\
\hline Traditional Race & $.029 *$ & 3.152 & .009 & .002 \\
\hline Dissatisfaction & .019 & 1.270 & .015 & .204 \\
\hline Anti-Barack Obama & $.054^{*}$ & 2.755 & .020 & .007 \\
\hline Right-media Skew & $.097 * *$ & 4.835 & .020 & .000 \\
\hline Republican & $.089 * *$ & 8.228 & .011 & .000 \\
\hline Conservative & $.074 * *$ & 5.089 & .014 & .000 \\
\hline $\mathrm{R}^{2}$ & .3196 & & & \\
\hline Number of cases & 2447 & & & \\
\hline
\end{tabular}

Notes: $* \mathrm{p} \leq .01 ; * * \mathrm{p} \leq .001$ 


\section{Discussion}

Political alienation, racial and ethnic tension, and religious nationalism are implicated in the politics of cultural differences because all involve challenges to the moral orders of some members of American society. For people on the right side of the American political spectrum, the Obama years seemed to devalue their political identity, racial status, and religious values. They responded positively to a Tea Party movement that sought to reassert those traits and restore them to primacy in the political culture. We believe that the cultural differences approach is the most powerful and parsimonious explanation for the major factors that directly and collectively influenced Tea Party support among the mass public. It provided a common thread that could draw together overlapping but not identical constituencies: political conservatives, white Anglos, religious traditionalists, racial conservatives, and advocates of gender complementarity.

In any model with so many predictors, it is likely that we will find some that behave contrary to expectations. We were most surprised that the four items about immigration did not exert a significant impact on Tea Party orientation. These were not the best measures we could have imagined, as their failure to form a scale attested, and they tended to focus on personal experience with immigrants rather than outrage about the larger impact of immigrants on American culture.

The Tea Party showed an impressive ability to unite factions that otherwise stood alone, As Montgomery recounted, (2012), Tea Party elites managed to overcome the long-standing tension between economic conservatives who wished to diminish the role of the state and moral traditionalists who wanted to harness state power to enforce their social code. These "frenemies with benefits," were united by portraying the state as the common enemy of both economic and religious freedom, paving the way for an alliance of convenience (Scher \& Berlet 2014, 106).

This was achieved with some sophistication. As was often noted by observers, Tea Party members distinguished between different kinds of government policies (Berlet 2012, Disch 2012, Williamson, Skocpol and Coggin 2011). The activists' vitriolic attacks on federal government programs usually exempted the two largest programs in the national budget: Social Security and Medicare. Tea Party recipients insisted that they "deserved" such social benefits, that they were rewards earned for hard work and obedience to traditional norms. By contrast, they attacked government efforts such as the Obama stimulus package, publicly-funded health care, and mortgage refinancing after the 2008 housing crash for promoting dependency and a sense of entitlement among people who did not follow the rules. As theories of cultural politics aver, a calculus of moral economy often underlies grievances justified in terms of economic orthodoxy (Oestreicher 1988). Far more than a veneer as it is sometimes portrayed in facile invocations of "culture war," moral economy is often central to the politics of cultural differences.

Republican discourse during 2016 U.S. presidential campaign exhibited marked similarity to the Tea Party rhetoric during its heyday. "Taking back America," the theme of the Trump campaign, meant unashamedly imparting Christian identity to the nation, restoring traditionalist 
gender and racial norms, and other cultural appeals to restore the moral order. Implicitly, it also referred to throwing out "career politicians" and bureaucrats who were blamed for what Trump called "American carnage." The tools of mobilization to achieve these ends included stoking powerful emotions of fear and anger via use of political symbols, framing grievances in terms of recapturing a country that lost its way, and politicizing group identity through an "us vs. them" social identity framework. It looks to us that Trump benefited considerably from the reordering of the Republican agenda that the Tea Party midwifed in 2009. 


\section{Notes}

${ }^{1}$ For previous analyses of Tea Party support, see Rosenthal \& Trost (2012) and Van Dyke \& and Meyer (2014).

${ }^{2}$ Higher values on sex, race and marital status were assigned, respectively, to men, whites, and married people.

${ }^{3}$ We chose an OLS model because the dependent variable orders respondents based on their increasing enthusiasm for the Tea Party.

${ }^{4}$ The only variables that performed differently in the OLS and MLE analyses were the dummies identifying miscellaneous Non-Christians and Latter-Day Saints.

\section{References}

Berlet, Chip. 2012. "Reframing Populist Resentments in the Tea Party Movement." In Steep: The Precipitous Rise of the Tea Party, ed. Lawrence Rosenthal \& Christine Trost. Berkeley: University of California Press, 47-66.

Burghart Devin and Leonard Zeskind. 2010. "Tea Party Nationalism: A Critical Examination of the Tea Party Movement and the Size, Scope, and Focus of Its National Factions." Kansas City, MO: Institute for Research and Education on Human Rights.

Chavez, Leo R. 2008. "Spectacle in the Desert: The Minuteman Project on the U.S.-Mexico Border." In Global Vigilantes: Anthropological Perspectives on Justice and Violence. Ed. David Pratten and Atreyee Sen. New York: Columbia University Press, 25-46.

Disch, Lisa. 2012. “The Tea Party: A "White Citizenship" Movement?" In Steep: The Precipitous Rise of the Tea Party, ed. Lawrence Rosenthal \& Christine Trost. Berkeley: University of California Press, 133-151.

Edsall, Thomas B. 2017 (May 18). "Why Republicans Are Always Looking over Their Shoulders." New York Times. Retrieved June 23, 2017 from https://www.nytimes.com/2017/05/18/opinion/republicans-trump-midterms-tea-party-edsall.html?mcubz=0.

Edsall, Thomas. 2016 (January 6). "Purity and Disgust." New York Times. Retrieved April 22, 2017 from https://www.nytimes.com/2016/01/06/opinion/campaign-stops/purity-disgust-anddonald-trump.html?_r=0.

Guth, James L. and John C. Green. 1993. "Salience: The Core Concept?". In Rediscovering the Religious Factor in American Politics. Ed. David C. Leege. Armonk, NY: M.E. Sharpe, 157176.

Hunter, James Davison. 1991. Culture Wars: The Struggle to Define America. New York: Basic Books.

Hunter, James Davison. 1994. Before the Shooting Begins: The Rise of Irreconcilable Differences in American Public Life. New York: Basic Books. 
Huntington, Samuel. 2004. Who Are We? New York: Simon \& Schuster.

Inglehart, Ronald and Pippa Norris. 2017. "Trump and the Populist Authoritarian Parties: The Silent Revolution in Reverse." Perspectives on Politics 15: 443-54.

Jacobs, Carly M. and Elizabeth Theiss-Morse. 2013. "Belonging in a 'Christian Nation': The Explicit and Implicit Associations between Religion and National Group Membership." Politics and Religion 6: 373-401.

Jones, Robert P. 2016. The End of White Christian America. New York: Simon \& Schuster.

Leege, David C. 1992. "Coalitions, Cues, Strategic Politics, and the Staying Power of the Religious Right, or Why Political Scientists Ought to Pay Attention to Cultural Politics." PS: Political Science \& Politics 25: 198-204.

Leege, David C., Joel A. Lieske and Kenneth D. Wald. 1991. "Toward Cultural Theories of American Political Behavior: Religion, Ethnicity and Race, and Class Outlook." In Political Science: Looking to the Future. Ed. William Crotty. Evanston, IL: Northwestern University Press, 193-238.

Leege, David C. and Kenneth D. Wald. 2007. "Meaning, Cultural Symbols, and Campaign Strategies." In The Affect Effect: Dynamics of Emotion in Political Thinking and Behavior. Ed. George E. Marcus, W. Russell Neuman, Michael MacKuen and Ann M. Crigler. Chicago: University of Chicago Press, 291-315.

Leege, David C., Kenneth D. Wald, Brian S. Krueger and Paul D. Mueller. 2002. Politics of Cultural Differences: Social Change and Voter Mobilization Strategies in the Post-New Deal Period. Princeton, NJ: Princeton University Press.

Markoff, John. 2015. Waves of Democracy: Social Movements and Political Change. Second edition. Boulder. CO: Paradigm Publishers.

Miroff, Bruce. 2007. The Liberals' Moment: The McGovern Insurgency and the Identity Crisis of the Democratic Party. Lawrence: University Press of Kansas.

Mockabee, Stephen. 2007. "A Question of Authority: Religion and Cultural Conflict in the 2004 Election." Political Behavior 29: 221-248.

Montgomery, Peter. 2012. "The Tea Party and Religious Right Movements: Frenemies with Benefits." In Steep: The Precipitous Rise of the Tea Party, ed. Lawrence Rosenthal \& Christine Trost. Berkeley: University of California Press,

Oestreicher, Richard. 1988. "Urban Working-Class Political Behavior and Theories of American Electoral Politics, 1870-1940." Journal of American History 74: 1257-1286.

Parker, Christopher S. and Matt A. Barreto. 2013. Change They Can't Believe In: The Tea Party and Reactionary Politics in America. Princeton, NJ: Princeton University Press. 
Postel, Charles. 2012. "The Tea Parties in Historical Perspective: A Conservative Response to a Crisis of Political Economy." In Steep: The Precipitous Rise of the Tea Party, ed. Lawrence Rosenthal \& Christine Trost. Berkeley: University of California Press, 25-46.

Public Religion Research Institute. "PRRI Poll: Race, Class and Culture Survey 2012," August 2012 [dataset]. USPRRI2012-RCC, Version 2. Public Religion Research Institute [producer]. Storrs, CT: Roper Center for Public Opinion Research, RoperExpress [distributor], accessed 14 June 2015.

Rosenthal, Lawrence and Christine Trost, Eds. 2012. Steep: The Precipitous Rise of the Tea Party. Berkeley. Berkeley: University of California Press.

Rovner, Julie. 2006. “'Partial-Birth Abortion:' Separating Fact from Spin." [Radio Broadcast Episode].” National Public Radio. Retrieved 10 June 2015 from http://www.npr.org/2006/02/21/5168163/partial-birth-abortion-separating-fact-from-spin.

Scher, Abby \& Chip Berlet. 2014. "The Tea Party Moment." In Understanding the Tea Party Movement, ed. Nella Van Dyke \& David S. Meyer. Burlington, VT: Ashgate, 99-124.

Sigelman, Lee and Stanley Presser. 1988. "Measuring Public Support for the New Christian Right: The Perils of Point Estimation." Public Opinion Quarterly 52: 325-337.

Steensland, Brian, Jerry Z. Park, Mark D. Regnerus, L. D. Robinson, W. B. Wilcox and R. D. Woodberry. 2000. "The Measure of American Religion: Toward Improving the State of the Art." Social Forces 79: 291-318.

Swidler, Ann. 1986. "Culture in Action: Symbols and Strategies." American Sociological Review 51: 273-286.

Van Dyke, Nella and David S. Meyer, eds. 2014. Understanding the Tea Party Movement. Burlington, VT: Ashgate.

Wald, Kenneth D. \& David C. Leege. 2010. "Mobilizing Religious Differences in American Politics." In Religion and Democracy in the United States: Danger or Opportunity? . Ed. Ira Katznelson and Alan Wolfe. Princeton, NJ: Princeton University Press, 355-381.

Wald, Kenneth D. \& David C. Leege. 2009. "Culture, Religion \& Politics.” In Oxford Handbook of Religion and American Politics. Ed. James A. Guth, Corwin D. Smidt and Lyman A. Kellstedt. New York, NY: Oxford University Press, 129-163.

Wildavsky, Aaron. 1987. "Choosing Preferences by Constructing Institutions: A Cultural Theory of Preference Formation." American Political Science Review 81: 3-21.

Williamson, Vanessa, Theda Skocpol and John Coggin. 2011. "The Tea Party and the Remaking of Republican Conservatism." Perspectives on Politics 9: 25-43. 
Wuthnow, Robert. 1987. Meaning and Moral Order: Explorations in Cultural Analysis. Berkeley: University of California Press.

\section{Acknowledgement}

The work on this manuscript was supported by the McNair Scholars Program at the University of Florida. We are grateful to the editor and reviewers for providing useful guidance in revising the paper. 